\title{
THE EXISTENCE OF GOOD GOVERNMENT GOVERNANCE LPSE AGAINST CONSPIRACY BY BUSINESSES IN PROCUREMENT OF GOODS AND SERVICES (INFRASTRUCTURE) IN PROTECTING THE INTEREST OF STAKEHOLDER
}

\author{
Yetti ${ }^{*}$, Associate Professor \\ Faculty of Law, University of Lancang Kuning, Indonesia \\ Onasis Dini, Lecturer \\ Faculty of Economics, University of Lancang Kuning, Indonesia \\ *E-mail: yetti arwendi@yahoo.com
}

\begin{abstract}
Good Government Governancein Electronic Procurement Services (LPSE) was created to reduce fraud, one of which is against conspiracy carried out by business Actors in the procurement of goods and services. The purpose of this research is to analyze the problems in the existence of Good Government Governance of Electronic Procurement Services (LPSE) against conspiracy conducted by business actors in the procurement of goods and services and to analyze the implementation of existing laws and regulations in providing penalties for perpetrators who commit conspiracy practices in project tenders. The method of this research is sociological law. The existence of Good Government Governance in Electronic Procurement Services (LPSE), still provides opportunities for conspiracy by business actors in the procurement of goods and services. It has not been able to meet expectations because of Human Resources, Technical Difficulties, and Funding Sources. The existence of Good Government Governance in Electronic Procurement Services (LPSE), apparently has not contained and provided the information needed by the community and is not yet transparent. The existence of Good Government Governance in Electronic Procurement Services (LPSE) has not been able to avoid the disputes made by business actors in the procurement of goods and services. It was found in the field research that the disputes could result in the project being not environmentally friendly and could neglect the interests of the local community. Recommendations: There is a need for coordination from each SKPD so that the e-tender carried out can be optimized. LPSE Pekanbaru City always makes various efforts so that the realization of e-tender as a process of procurement of goods and services that can be well implemented.
\end{abstract}

\section{KEY WORDS}

Conspiracy, Good government governance, community, stakeholders.

Construction of facilities and infrastructure for the benefit of the community is carried out by tender. The meaning of tender is broadened to the selection of providers of government goods/services (BPJB) which is carried out openly and can be followed by all registered providers of goods/services by submitting a bid within the allotted time. By lex specialis, tenders are the same as auctions (Mario A. Tedja, 2013).

Tender is one mechanism that must be passed to get a project procurement of goods and services within the scope of Government. The term "procurement" means the provision of government goods and services to meet government needs.

One of the legal bases underlying the E-Procurement process is Presidential Regulation No. 54 of 2010 concerning the obligation of announcing the auction for the procurement of goods and services through the website which has been affirmed in Article 1 number 37 of Presidential Regulation No. 54 of 2010 (Adrian Sutedi, 2012).

The main objective in the tender is to provide equal opportunities for all bidders, so as to produce a minimum price, with maximum results. Although the very low price is not the 
only measure to determine the winner in the procurement of goods or services (Firoz Gaffar: 2006).

The regulation regarding the prohibition of tender conspiracy can be applied both with a rule of reason approach and with an illegal per se approach (Mukhibah, 2009).

Prohibition of conspiracy is an attempt by the government so that the community (stakeholders) as the end-users of the infrastructure are not harmed by the imperfections of infrastructure that are carried out by the winner of the tender, and can guarantee the protection of the environment around the area of infrastructure development.

However, in practice, sometimes the auction winner does not carry out the Work Plan in accordance with the agreement, thus causing harm to the local community, where the implementation of the work causes damage to the local environment, thus causing various losses to the community and the local environment.

It is because there has been a dispute between the Government (as the owner of the auction) and the business actor who won the auction, so the funds are not optimally used to meet work standards, resulting in harm to the environment and the local community, while the supervision by the government as the owner the auction states that the work has met the quality standards of a project. It occurs due to the conspiracy, where one of the objectives is the results of the project being monitored and evaluated by the government can fulfill the desire of the auction winner.

The case of Hambalang (sports infrastructure development), which is worth hundreds of billions, is neglected due to disputes that result in social and economic losses of the local community, where one of the objectives of the Hambalang project is to improve the economy of the local community.

The case Sei Merangin Bridge in Kampar Regency, Riau Province, where the Contractor was sued by the local community because the contractor damaged their environment and there was no compensation from the contractor.

The cases above are project deals through Electronic Procurement Services (LPSE), yet still, cause problems to the environment and local communities.

In fact, to improve Good Government Governance in the auction, the government created LPSE in an effort to protect the public and stakeholders from the winner of the auction.

In a different case, there is the case occurred in the auction of the Sei Paku Irrigation Area Rehabilitation Work Plan, Kampar District 2013. The source of funds was from the Department of Public Works (PU), which was won by PT Tunggal Jaya Santika. PT Tunggal Jaya Santika won with an offer of Rp 11,832,114,000, dated 4 March 2013, through an appointment letter IK.01.02/48/SPPBJ-IR.II/2013.

Other companies that participated in this offer are PT Dwi Mulia Agung Utama, PT Paluh Indah, PT Usaha Kita Abadi, PT Lamsaruly Artha Kencana, PT Fatimah Indah Utama, PT Minarta Duta Hutama, PT Riau Rancang Bangun, and PT Morasait Elibu Jaya. PT Tunggal Jaya Santika is in the period of receiving a blacklist sanction from the Government Goods/Services Procurement Policy Agency (LKPP), for the period of January 4, 2013, to January 3, 2015.

Black List is a list that contains the identity of the Goods/Services Provider and/or Issuer of Guarantee that is sanctioned by the Budget User/Budget User Authority in the form of a prohibition to participate in the procurement of goods/services throughout the Ministries/Institutions/Work Units of the Regional Apparatus/other Institutions. Sumatra III Water Utilization Network Operator in Riau Province, Jl Cut Nyak Dien, Pekanbaru (http://kelilingriau.blogspot .co.id/ 2013/06/ perusahaan-blacklist-menang-tender-di.html).

The second case is a project in the Sumatra River Basin Regional Work Unit (BWSS) III of the Directorate General of Water Resources of the Ministry of Public Works which was allegedly carried out by a blacklisted company, PT Ganesha Bangun Riau Sarana (GBRS). PT GBRS was announced on April 20, 2014, as the winner of the 2014 BWSS Heavy Equipment Workshop Project construction budget year 2014 worth Rp 2,380,015,000, while apparently being included in the company Black List. 
Furthermore, PT GBRS, with Taxpayer Identification Number (NPWP) 01,894,519.6211,000, was blacklisted from 28 February 2014 to 27 February 2016. (https://www.merdeka.com/peristiwa/proyek-kemen-pu-dikerjakan-perusahaan-blacklist-dipekanbaru.html).

Problem Formulations are:

- How is the Existence of Good Government Governance in Electronic Procurement Services (LPSE) Against Conspiracy carried out by Business Actors in the Procurement of Goods and Services?

- How is the Existence of Good Government Governancein Electronic Procurement Services (LPSE)?

- How is the implementation of the existing laws and regulations in providing penalties for perpetrators who commit unfair practices in project tenders?

\section{LITERATURE REVIEW}

In selecting qualified partners/contractors, an election process called a tender is needed. Tenders are activities aimed at selecting, obtaining, assigning and appointing the most appropriate companies to work on a plan (Aditya Purnama, Dedy Handoko, Masri Rumita, 2014).

Among the tender players is the Contractor. Another understanding of the contractor is derived from the word "contract" means a letter of agreement, contract agreement, or lease (http://www.alkonusa.com/news/definisi-kontaktor/) needs to have a competitive bidding strategy as the information and communication technology advances to win project tenders. A large number of companies will lead to competition in the construction services business which tends to be unfair (Lisca Vontya Arifin, 2015).

Since January 1,2013, all plans of goods and services procurement projects in Pekanbaru City must be auctioned through the Electronic Procurement Service (LPSE). This is in accordance with the circular of Government Goods/Services Procurement Policy (LKPP). So later, each agency is required to announce plans for the procurement of goods/services via online auctions through LPSE. Then agencies can form one or more goods/service procurement service units consisting of personnel who already have a certificate of goods/service procurement expertise.

The preparation of establishing an electronic goods and services procurement agency (LPSE) started in 2008. The electronic goods and services procurement system are based on Presidential Decree No. 80 of 2003 which regulates the procedures for the auction of goods and services. This Presidential Decree was amended to the new Presidential Decree No. 54 of 2010 which contains procedures for the auction of goods and procurement of goods and services which are carried out electronically (E-procurement).

E-Procurement is the online process of procurement of goods and services via the internet, where the entire announcement, registration, bidding process, aanwijzing process, and evaluation results of the offer are carried out by utilizing information technology facilities (Mochammad Jasin, 2007).

The most important thing is that e-Procurement specifically, or the procurement of government goods/services, in general, must be in favor of improving the quality of public services, good governance, and the welfare of the people which are stated in the concept of good governance ( Samsul Ramli, 2013).

The implementation of e-procurement is an important step in supporting the implementation of public information disclosure as regulated in Law No. 14 of 2008 concerning Public Information Openness. According to the draft regulation, starting in 2012 all goods/services procurement auctions conducted by government agencies must be conducted electronically.

In any case, commitment and competence are very important. Especially in relation to the use of a system, such as e-Procurement. Many parties really yearn for the realization of a system of procurement of goods/services that is transparent and accountable through this e- 
Procurement system, but it often leads to doubts about the reliability of the system (Samsul Ramli, 2013).

In an effort to enforce this legal aspect, we need a regulation that can be used as a reference in the implementation of electronic transactions to ensure the validity of the transaction, including correspondence through electronic media such as legal aspects of electronic signatures, and stamp duty for various documents. In this case also needed a guarantee for the validity of auditing the auction/tender process through electronic media (eProcurement) (Tutang Muchtar, 2011) for the validity of auditing the auction/tender process through electronic media (e-Procurement).

LPSE is a system created to establish the values of good governance in the procurement of goods and or services that are protected by the APENDO (document security application) from the State Intelligence Agency (BIN) (LPSE PU, 2013).

The term conspiracy itself was first stated in the Antitrust Law in the USA originating from the jurisprudence of the United States Supreme Court, namely the provisions of Article 1 of the Sherman Act 1890, 41 wherein the article the Supreme Court formulated that business actors must be proven based on a conspiracy (Mustafa Kamal Rokan, 2012).

In the sense that is commonly accepted in the United States, conspiracy is the union of opinions and views generated by a meeting to take action together (Asril Sitompul, 1999).

However, conspiracy is often considered equivalent to the term collusion, which is a "secret agreement between two or more people for deceitful or fraudulent purposes", meaning that in the collusion there is a secret agreement made by two or more people with the purpose of fraud or embezzlement, which is the same as conspiracy and tends to have negative connotations (bad) (Elyta Ras Ginting, 2001) without involving other business actors to win unfair business competition (Suharsil and Mohammad Taufiq Makaro, 2010).

The form of conspiracy activities does not have to be proven by an agreement, but it can be in the form of other activities that are not possible to be realized in an agreement (Rachmadi Usman, 2013).

In Article 22 of Law Number 5 of 1999, a tender is an offer to submit a price to do an entire job, to procure goods or to provide services (Journal of Business Competition KPPU, 2013). For reasons of effectiveness and efficiency, rather than carrying out the project alone, it is turned over to other parties who have the capability to carry out the project (Syamsul Ma'rif, 2002). In practice, the notion of tender is the same as that of auction (Hendah Lahyunita K, "2013).

A public auction is a method of selecting suppliers of goods/ services which is carried out openly with public announcements (Andi Fahmi Lubis, et.al, 2009).

The definition of the tender includes an offer to bid for: (Rachmadi Usman, 2013): doing an entire job; procuring goods and/or services; purchasing goods and/or services; trading goods and/or services.

Two or more business actors will compete in submitting the price of a project offered so that if there is only one bidder, the choice of the work owner will become increasingly limited (Hikmahanto, 1999).

Tender Committee or Procurement Officers are civil servants, both from their own agencies and other technical agencies. Employment the Committee from work units/agencies/ departments/ other institutions is because the institution conducting the procurement of goods/services does not have employees who understand the technical problems in the provisions of the procurement of goods/services, type of work, and the contents of the procurement document of the work to be performed (pengadaan.blogspot.co.id).

The number of Procurement Committees is determined by the value of the procurement and the type of procurement to be carried out. As described in Article 16 of Presidential Regulation No. 70 of 2012 which is the second amendment to Presidential Regulation No. 54 of 2010, the Procurement of Goods/ Construction Services/Other Services with the highest value of Rp. 500,000,000.00 (Five Hundred Million Rupiahs) can be carried out by at least three people, while for the Procurement of Goods/Construction Services/Other Services above Rp.500,000,000.00 (Five Hundred Million Rupiah) is carried out by at least 
five people. Procurement of Consultancy Services with the highest value of Rp. 200,000,000.00 (Two Hundred Million Rupiah) can be carried out by at least three people. As for the Procurement of Consulting Services valued at over Rp. 200,000,000.00 (Two Hundred Million Rupiah), the committee should consist of at least five people.

Tender conspiracy is the actions of other business actors to dominate the market by regulating and/or determining the winner of the tender so that it can lead to unfair business competition (Mustafa Kamal Rokan, 2012).

The actors consist of two or more entrepreneurs. In Article 22 it is stated that tender conspiracy can occur not only between business actors but also other parties. It is to anticipate legal loopholes that tender conspiracy can occur not only between business actors (corporations) but also between business actors and individuals. In this case, the individuals can be the owner of the job as well as the tender committee, or individuals who have access to the work owner in which this access can influence the decision of the work owner to determine the winner of the tender (Mustafa Kamal Rokan, 2012).

The elements of conspiracy include: cooperation between two or more parties; openly or secretly make adjustments to documents with other participants; comparing tender documents before submission; creating sham competition; agreeing or facilitating conspiracy; not refusing to take any action despite knowing or duly knowing that the action was carried out to arrange (Article 1 Paragraph 6 Chapter I General Provisions of Law Number 5 the Year 1999) in order to win certain tender participants, Giving exclusive opportunities by the tender organizer or related parties directly or indirectly to business actors who participate in the tender by means of violating the law (Yetti, 2011).

Cooperation between the parties in the conspiracy must be proven to aim to arrange and/or determine the winner of the tender (Mhd. Dahlan Surbakti, 2015). Therefore, conspiracy in tenders has a dual purpose, namely to dominate the market and arrange and/or determine the winner. (Rachmadi Usman).

Unfair business competition is a competition among business actors in carrying out production and/or marketing activities of goods and/or services conducted in a way that is not honest or against the law or inhibits business competition (Article 1 Paragraph 6 Chapter I General Provisions of Law Number 5 the Year 1999).

\section{METHODS OF RESEARCH}

This research is a sociological legal research. Sampling from the population includes all the characteristics/properties possessed by the subject or object (Sugiono, 2013).

Table 1 - Table of Population And Sample

\begin{tabular}{|c|c|c|c|c|}
\hline No. & Type of Population & Population & Sample & Percentage \\
\hline 1 & LPSE Chairperson & 1 & 1 & $100 \%$ \\
\hline 2 & Information system administration support staff & 5 & 1 & $20 \%$ \\
\hline 3 & Budget User (PA) & 3 & 3 & $100 \%$ \\
\hline 3. & Commitment-Making Officer (PPK) & 1 & 1 & $100 \%$ \\
\hline 4. & Commitment-Making Officer (PPK) & 1 & 1 & $100 \%$ \\
\hline 5. & Pokja ULP & 6 & 2 & $33,3 \%$ \\
\hline 6. & Secretary & 3 & 1 & $50 \%$ \\
\hline 7. & Local Community & 40 & 15 & $37 \%$ \\
\hline \multicolumn{2}{|r|}{ Total } & 60 & 25 & - \\
\hline
\end{tabular}

\section{Data Source:}

1. Primary data, namely data obtained from respondents in the field through interviews with informants;

2. Secondary data, namely data from various literature, laws, and regulations related to research;

3. Tertiary data, namely data that support primary and secondary data in the form of dictionaries and encyclopedias. 


\section{RESULTS AND DISCUSSION}

Good Government Governance of procurement of goods or services for a project of a company or government agency is often carried out by means of a tender process. The intention of the tender organizer is to get the price of goods or services as cheap as possible, but with the best quality possible. The main objective of the tender can be achieved if the process takes place in a fair and transparent manner, in which the winner is truly determined by the offer (price and quality of goods or services submitted). The opposite could have occurred if there was a bid-rigging in the tender process. The term "conspiracy" is essentially contradicting with justice because it does not provide equal opportunities for all bidders to obtain objects of goods and services offered by the organizer. As a result of the tender conspiracy, bidders with good intentions are hampered from entering the market and the further consequence is the creation of uncompetitive prices.

In Indonesian business competition law, "tender" is defined as bidding for prices to do an entire job, to procure goods or to provide services. The offer is made by the owner of the activity or project. For reasons of effectiveness and efficiency, rather than carrying out the project alone, it is turned over to other parties who have the capability to carry out the project. In Article 22 of the Law No. 5 of 1999 conspiracy or business conspiracy is defined as a form of cooperation carried out by business actors with other business actors with an intention to control the relevant market for the interests of business actors who are involved in the conspiring. Article 22 states: "Business actors are prohibited from conspiring with other parties to arrange and determine the winning bidder so as to result in unfair business competition".

The tender for the procurement of government goods and services is inseparable from a conspiracy. A significant increase in the number of goods and services of the government requires the Government to improve the system of procurement of service and goods that are better for producing goods and services needed. In essence, the implementation of tenders must fulfill the principles of justice, openness, and non-discrimination. In addition, tenders must pay attention to matters that comply with the principle of fair business competition. This was anticipated by means of Electronic Procurement Services (LPSE).

The Existence of Good Government Governance in Electronic Procurement Services (LPSE) Against Conspiracy is carried out by business actors in the procurement of goods and services. However, there are some occurrences of companies that have been blacklisted but still take part in tenders and even the said companies won the tenders. Article 24 of Law No. 5 of 199 states that Business Actors are prohibited from engaging in conspiracy with other parties to inhibit the production and/or marketing of goods and/or services of competitors, with the intention that the goods and/or services offered or supplied in the relevant market will be reduced in terms of quantity, quality, and timeliness. as required. The provision of Article 24 is already in line with President Regulation Number 54 of 2010 and the amendment which explains that one of the acts or actions of a service or goods provider that may be subject to sanctions is to conspire with other providers of service and goods to control the bid price outside the procedures for implementing the procurement of service goods, thereby reducing, inhibiting, minimizing, and/or eliminating fair competition and/or harming other people.

However, this existing regulation cannot tackle the conspiracy. Supervision of the system of procurement of goods and services cannot be carried out. This happens because not all bidders submit the auction file into the online system. The reason is the difficulty of uploading files into the online system, so partners still do it manually. Thus, online monitoring cannot be carried out.

Actually, there is a supervisor institution that has been referred by the government based on Presidential Decree No. 75 of 1999, namely the Business Competition Supervisory Commission (KPPU), to ensure the supervision of business implementation, so that it can run properly. Law 5 of 1999 mandates the formation of a commission to maintain and supervise business competition. KPPU was formed to supervise business actors in their business activities so as not to do monopolistic practices and/or unfair business competition, 
which would clearly harm MSMEs. However, nineteen years since the establishment of KPPU, this institution has not reached Riau while it should have existed for each province. It should be in accordance with the law that conspiracy is a prohibited activity included as a category of unfair business competition. The absence of KPPU in Pekanbaru (Riau) is what must be addressed in implementing LPSE.

LPSE itself operates an e-procurement system called SPSE (Sistem Pengadaan Secara Elektronik/Electronic Procurement System) developed by LKPP. At first, LPSE was only an ad hoc team formed by the head of the agency (governor, mayor, minister). In further developments, some agencies such as the Ministry of Finance of the Republic of Indonesia, West Java Province, and West Sumatra Province have structurally established LPSE. In the procurement process, LPSE only acts as a facilitator who does not participate in the procurement process. The procurement process is fully carried out by the procurement committee or the Procurement Services Unit/ULP. The legal basis of this service are Presidential Decree Number 80 of 2003 concerning Guidelines for the Implementation of Procurement of Public Goods and Services, Presidential Instruction Number 5 of 2003 concerning Economic Policy Plan Towards and After the End of the Cooperation Program with the International Monetary Fund (IMF), Presidential Instruction Number 52004 concerning the Acceleration of Corruption Eradication, Presidential Regulation No. 8/2006 concerning the Fourth Amendment to Presidential Decree No. 8/2003 (concerning Guidelines for the Implementation of Government Goods and Services Procurement). Presidential Decree No. 80 of 2003 regulates the procurement of goods and services financed by the State Budget (APBN) and the Regional Budget (APBD). The Presidential Decree does not yet regulate e-Procurement procedures. Recently there are central, regional and state government agencies in Indonesia that procure goods and services through E-Procurement (Waraswati, 2005: Suara Karya) in the form of e-procurement. E-procurement is the process of supervising tender announcements, the mechanism for winning a tender until the implementation of the tender should be the duty and authority of the LPSE. The implementation of government procurement of goods and services is financed by the State Budget and Regional Budget.

Legally, even though E-Procurement uses the internet as an auxiliary instrument, it does not mean that an agreement between the procurement committee and the participant of the supplier of goods takes place on the internet as it does in E-Commerce. E-Procurement is not yet a fully paperless transaction because, in addition to inputting data through the portal, goods providers are also required to provide bid documents and other related data in the form of hard copy to the Procurement Committee. Then, a Decree on the Declaration of the Provider of Goods and Services (SKPPBJ) is issued; it designates one of the bidders as the winner of the auction. Since E-Procurement still emphasizes on the tangible form or paper-based transaction, it does not fully conduct electronic commerce like E-Commerce. It means that the rules of the treaty law still apply (www.//adin/lib.unair.ac.id/). The objective of procuring goods and services will be achieved if all parties are involved in the procurement process and follow the applicable norms. A new norm exists if there is more than one person because the norm basically regulates the manner in which a person behaves towards other people or the environment (Indrati, 1998: 23). Similar to other norms, norms for the procurement of goods and services consist of unwritten norms and written norms. Unwritten norms are generally ideal norms while written norms are operational. The procurement of goods and services must be carried out based on the principles of procurement.

Presidential Decree 54 of 2010 regulates the implementation of the procurement of goods and services so that it runs in accordance with the rules and regulations applied. Starting in 2012, efforts to conduct the procurement of goods and services through an eprocurement auction have been made. The ULP Working Group stated that the eprocurement system brings some benefits as it is more efficient and effective in terms of the relatively short auction time of 21 working days (30 calendar days) that could be reduced to 14 working days. In accordance with the concept of the type of benefit or benefits generated according to Grindle, that the benefits generated are related to how and to what extent the implementation of public policy brings changes in the behavior of the parties concerned. 
Thus, the general logic applies if the implementation of regulation takes the form of a policy that benefits the parties, and then the parties will provide support for the policy.

The existence of Good Government Governance in Electronic Procurement Services (LPSE) has not been able to avoid the conspiracy by business actors in the procurement of goods and services. In the field research, it turns out that this conspiracy lead to a problem, wherein the conspiracy the winner has a hidden agreement which results in funds provided by the State being allocated into matters that can reduce the value of the project's material standard, and can ignore the interests of the community and the environment because the winner only wants to meet the standard of the project. The materials may not be environmentally friendly and it ignores the interests of the local community, because if it is environmentally friendly then the winner needs a substantial amount of funds, so that these funds can be diverted and used to fund the conspiracy.

The existence of Good Government Governance in Electronic Procurement Services (LPSE), apparently has not optimally contained and provided the information needed by the community. It is also not transparent. Based on the results of research in the field, it was found that in LPSE there was no information that protected the community and there was no information available for the community for example in the case of construction of the Merangin SEl bridge in Kampar Regency, Riau Province. The community demanded compensation from the winner of the bridge project (who carried out the Project) for the loss suffered by the community which resulted in damage to the houses and the community around the bridge construction project. However, the company refused to provide compensation on the grounds that compensation was not the responsibility of the company but it was the responsibility of the district government, while the budget originated from the provincial budget. That was the reason why the rights of local communities were ignored. The community was unsure where to demand compensation because when they sued the district government, it was rejected on the grounds that it was not a district government project.

This case shows that the information in LPSE does not meet the expectations and needs of the community because the community cannot find information regarding who is responsible when there is a claim for compensation. The information available on LPSE only tells the total value of the Project and the time of its implementation. In detail, the costs available to LPSE are not informative. In addition, there is no information available regarding legal matters with the local community and the environment, causing information gaps for the community.

By not being open and informative about the information, LPSE has caused losses to the local community, so that the local community can no longer fulfill their family's material needs.

The existing legislation that stipulates penalties for perpetrators who commit unfair conspiracy in project tenders is not well implemented. Bidders who have been blacklisted can still submit tender requests and follow the process.

This happens due to several factors, including human resources that is very important factor that is inseparable from an organization striving to achieve an effective program implementation. Human resource is an internal factor in the process of procurement of goods and services in LPSE Pekanbaru City. The number of human resources greatly influences the process of procurement of goods and services.

The committee is directly involved in several fields of the e-tender. In order to help the committee to focus on the procurement of goods and services, a lot of training and simulations of the work of the procurement of goods and services plan are needed. That is one of the obstacles. Moreover, the workload is not balanced with the number of committees, which leads to late completion of the process as the committee requires time and focus on completing one plan. "(Interview with ULP working group, 15 March 2018)

Based on the interview, the human resources in the procurement of goods and services in LPSE Pekanbaru City are still not balanced with the number of existing procurement plans so the plan is rather late in completion. In addition, the committee really needs training and work plan simulations to focus on the procurement of goods and services. 
Technical difficulties have a major influence on the implementation of the procurement of goods and services. The technical difficulties include the insufficiency of infrastructure. The major problem is limited internet connectivity. The available bandwidth is still very limited. A better internet network is required to support the procurement of goods and services. Connectivity issues greatly affect the implementation of the procurement of goods and services because the procurement process of e-procurement uses online features. Registration, data management, and the announcement are done through the internet.

Connectivity problems often occur when uploading or downloading procurement files. The network disruption itself is actually from the center. Sometimes it is difficult to log in. However, it is still reasonable, considering the nature of internet connection. Usually, the network problems do not take a long time, only about one to two hours" (Interview with the Chairperson of LPSE Pekanbaru City, 15 March 2018).

The source of funding is an effort made by the government to raise funds used as operating costs and managing the procurement of goods and services from the regional budget. An adequate source of funding is required to operate computerized and internetbased LPSE services as well as implementing electronic goods and services procurement in LPSE Pekanbaru City. The application of e-procurement requires some substantial costs, such as the construction of infrastructure, equipment, servers, data centers, and security as well as the cost for network maintenance". (Interview with the Chairperson of LPSE, 15 March 2018).

The interviews reveal that LPSE requires a great fund. Computerized systems and internet services ensure substantial costs to operate. To support the smooth access to LPSE services, the provincial government has budgeted funds for the procurement of computers and networks, as well as maintenance and payment of salaries for LPSE officers. On the other hand, the LPSE system has been recognized to provide efficiency for both service users and service providers. However, the e-procurement through LPSE services requires a large cost. In this case, the provincial government must prepare a budget to guarantee network quality and internet security in Pekanbaru City LPSE.

Black List is a list that contains the identity of the Goods/Services Provider and/or Issuer of Guarantee that is sanctioned by the Budget User/Budget User Authority in the form of a prohibition to participate in the procurement of goods/services throughout the Ministries/Institutions/Work Units of the Regional Apparatus/other Institutions.

A project in the Sumatra River Basin Regional Work Unit (BWSS) III of the Directorate General of Water Resources at the Ministry of Public Works was allegedly carried out by a blacklisted company, PT Ganesha Bangun Riau Sarana (GBRS). PT GBRS was announced on April 20, 2014, as the winner of the 2014 BWSS Heavy Equipment Workshop Project construction budget year 2014 worth $\mathrm{Rp} 2,380,015,000$ while the company was still in the blacklist.

PT GBRS, that is located in Jalan Datuk Setia Maharaja Blok B-7, Office of Grand Sudirman Tangkerang Selatan Bukit Raya District, Pekanbaru, Riau, was put on a blacklist on June 13, 2014.

PT GBRS with Taxpayer Identification Number (NPWP) 01,894,519.6-211,000 was blacklisted from 28 February 2014 to 27 February 2016. Written reports related to projects using the regional funds were carried out by companies included in the LKPP Blacklist.

One of the rules according to Presidential Regulation Number 54 of 2010 and its amendments to be followed up further through the Head Regulation (Perka) of LKPP is the rules regarding the establishment of a blacklist. (Interview with Head of Public Relations and Public Relations of the Attorney General's Office) Attorney Riau Mukhzan MH

Blacklist sanctions are sanctions given to goods/service providers who violate provisions in the field of goods/services procurement. The sanction is in the form of a prohibition to participate in goods/services procurement for 2 years. As of August 31, 2014, the applicable regulation was Perka LKPP Number 7 of 2011 concerning Blacklisted Technical Operational Guidelines. However, since September 1, 2014, LKPP has issued a substitute regulation namely Perka LKPP Number 18 of 2014 concerning the Black List in Government Goods/Services Procurement. 
Another similar case is the case of the Sei Paku Irrigation Area Rehabilitation Work Plan in 2013 in the Kampar Regency. PT Tunggal Jaya Santika won with an offer of Rp $11,832,114,000$, dated 4 March 2013, through a letter of appointment IK.01.02/48/SPPBJIR.II/2013. Other companies participating in this offer were PT Dwi Mulia Agung Utama, PT Paluh Indah, PT Usaha Kita Abadi, PT Lamsaruly Artha Kencana, PT Fatimah Indah Utama, PT Minarta Duta Hutama, PT Riau Rancang Bangun, and PT Morasait Elibu Jaya. PT Tunggal Jaya Santika was in a blacklist sanction from the Government Goods/Services Procurement Policy Agency (LKPP) for the period of January 4, 2013, to January 3, 2015.

Actions that can be subject to blacklist punishment:

- Absence in proving qualifications may abolish sanctions for blacklisting offering, accepting, or promising to give or accept gifts or rewards of any kind or take other actions to influence anyone who is known or reasonably suspected of being related to the Procurement of Goods/Services are now subject to blacklist sanctions;

- Not repairing or replacing defective goods within the stipulated period may also be subject to blacklist sanctions;

- The emphasis that not following up on the BPK audit results that result in state financial losses may be subject to blacklist sanctions;

- Provisions regarding blacklisted witnesses for guarantee issuance were abolished;

- Both the head office and branch offices, if subjected to blacklist sanctions, will apply to the head office and other branches. This does not apply to the parent and subsidiary;

- In the process of proposing blacklist sanctions, PPK/Pokja ULP/Procurement Officers are required to make clarifications attended by the provider. The output of the clarification is the Minutes of Examination;

- PPK/WG ULP/Procurement Officer is obliged to disclose the copy of the proposal to determine the blacklist sanction to the provider so that the provider has the right to submit an objection before the issuance of the blacklist sanction by PA/KPA;

- The PA/KPA cannot immediately stipulate blacklist sanctions. It must ask for a recommendation from APIP. APIP is obliged to examine whether the provider has indeed committed a violation;

- The period of blacklist sanctions issued by BUMN/BUMD, donor agencies, other state governments, and/or the Business Competition Supervisory Commission (KPPU) follows the stipulated time period. So it doesn't have to be two years. It can be less or more than two years;

- A blacklist that has been released can only be canceled through a court decision that has permanent legal force.

This refers to President Regulation No. 70 of 2012 concerning the procurement of goods and services, which among others emphasizes that LKPP must be updated at all times and it does not apply retroactively to a process. That is, they first announced the winner, rather than knowing the issuance of the blacklist on behalf of the company. Then it does not receive objection during the refutation period that has been given from February 21February 27, 2013.

The blacklist was set to take effect in January, so it was strange that LKPP only updates the data for June until six months detained by LKPP since the determination.

\section{CONCLUSION}

The existence of Good Government Governance in Electronic Procurement Services (LPSE) still provide opportunities for conspiracy by business actors in the procurement of goods and services. It has not been able to meet the expectations because of Human Resources, Technical Difficulties, and Funding Sources.

The existence of Good Government Governance in Electronic Procurement Services (LPSE), apparently does not contain and provide the information needed by the community. Moreover, it is not yet transparent. 
The existence of Good Government Governance in Electronic Procurement Services (LPSE) has not been able to avoid disputes by business actors in the procurement of goods and services. It was found in the field research that the disputes could result in the project being not environmentally friendly and could neglect the interests of the local community.

The existing laws and regulations are not well implemented in providing penalties for perpetrators who commit unfair conspiracy practices in project tenders. The proof is that tender participants who have been blacklisted can submit tender requests, take part in the tender process and win the tender.

Government efforts in creating various supervisory Institutions and procedures (Electronic Procurement Services (LPSE) to create good governance cannot be maximized due to human resources (Persons) in various government institutions who still commit fraudulent actions.

\section{RECOMMENDATIONS}

In Good Governance, LPSE is required to provide the information needed by the public, not only the information needed by tenders. Issuance of rules and regulations that support and protect the interests of the community and the environment from the actions of tenders that harm the community and the environment.

\section{REFERENCES}

1. Aditya Purnama, Dedy Handoko, Masri Rumita, penegakan hukum persekongkolan tender yang diatur dalam Pasal 22 Undang-Undang Nomor 5 Tahun 1999 tentang Larangan Praktik Monopoli and Persaingan Usaha Tidak Sehat belum berjalan secara optimal. Jurnal Hukum Bisnis Vol II No 4, 2014.

2. Adrian Sutedi, Kebijakan Pengadaan Barang and Jasa and Pembaruannya, dalam Aspek Hukum Pengadaan Barang and Jasa and Berbagai Permasalahannya, Sinar Grafika, Jakarta, 2012.

3. Andi Fahmi Lubis, et.al, 2009, Hukum Persaingan Usaha Antara Teks \& Konteks, Jakarta, ROV Creative Media.

4. Asril Sitompul, 1999, Praktik Monopoli and Persaingan Usaha Tidak Sehat, Bandung, Citra Aditya Bakti.

5. Elyta Ras Ginting, 2001, Hukum Anti Monopoli Indonesia: Analisisi and Perbandingan Undang- Undang Nomor 5 Tahun 1999, Bandung, Citra Aditya Bakti.

6. Firoz Gaffar, "Hukum Acara Persaingan Usaha: telaah kritis atas sejumlah problem "Hukum Bisnis 25 No. 1 (Mei 2006): 63.

7. Hendah Lahyunita K," Tinjauan Mengenai Pengaturan Monopoli Berdasarkan Hukum di Indonesia,"Jurnal antimonopoli, Vol II N0. 32013.

8. Lisca Vontya Arifin Tinjauan Yuridis Terhadap Persekongkolan Tender Berdasarkan Pasal 22 Undang-Undang Nomor 5 Tahun 1999 Tentang Larangan Praktik Monopoli and Persaingan Usaha Tidak Sehat Jurnal JOM Fakultas Hukum Volume II No. 1 February 2015.

9. LPSE PU, "Sekilas e-Procurement PU", http://lpse-pu.kompetisiog.com/sample-page/, accessed on 12 January 2013.

10. Mario A. Tedja, Persekongkolan Tender Dalam Praktek Monopoli and persaingan Usaha Tidak Sehat di Indonesia Jakarta, 2013.

11. Mhd. Dahlan Surbakti, "Menguasai and Penawaran Tender Sebagai Masalah Hukum dalam Pelaksanaan Pengelompokan Bank: Hukum Perdagangan 24 No. 3 ( 2005),33Hikmahanto, sekilas tentang Hukum Persaingan and UU No. 5 tahun 1999,Magister Hukum, Edisi 2 no 1, (1999) Hukum bisnis.

12. Mochammad Jasin, 2007, Mencegah Korupsi Melalui E-procurement, Komisi Pemberantasan Korupsi, Jakarta.

13. Munir Fuady, 1999, Hukum Anti Monopoli Menyongsong Era Persaingan Sehat , Bandung, Citra Aditya Bakti. 
14. Mustafa Kamal Rokan, 2012, Hukum persaingan Usaha, Jakarta, Rajawali Pers.

15. Onasis, D. (2017). Pengaruh Good Corporate Governance terhadap Manajemen Laba Perusahaan Industri Manufaktur Basic Industri yang Terdaftar di Bursa Efek Indonesia. Jurnal IImu Komputer and Bisnis, 8(1), 1847-1856.

16. Rachmadi Usman, 2013, Hukum Persaingan Usaha Di Indonesia, Jakarta, Sinar Grafika.

17. Samsul Ramli, 2013, Bacaan Wajib Para Praktisi Pengadaan Barang/Jasa Pemerintah, Visimedia, Jakarta.

18. Sugiono, Metode Penelitian Pendidikan (Pendekatan Kuantitatif, Kualitatif, and R\&D), (Bandung: Alfabeta, 2013).

19. Suharsil and Mohammad Taufiq Makaro, 2010, Hukum Larangan Praktik Monopoli and Persaingan Usaha Tidak Sehat di Indonesia, Bogor, Graha Indonesia.

20. Syamsul Ma'rif, "Tantangan penegakan hukum persaingan usaha di Indonesia: Kemudahan monopoli yang diberikan kepada syarikat merupakan usaha untuk menarik kesediaan pelabur menanamkan asetnya disektor tersebut Jurnal Hukum Bisnis 19 No. 3 (2002).

21. Tutang Muchtar, "Implementasi Pengadaan Secara Elektronik (E-Procument) di LPSE Provinsi Sulawesi Tengah", Jurnal Infrastruktur, Vol.1 Nomor 1, Juni 2011.

22. Law Number 5 of 1999, tentang larangan Amalan Monopoli and Persaingan Usaha Tidak Sihat.

23. President Regulation Number 4 of 2015 concerning the Fourth Amendment to Presidential Regulation Number 54 of 2010 concerning Procurement of Government Goods/Services.

24. Jurnal Melayunesia Law, Vol 1, No 1, December 2017 P-ISSN: 2580-7447/E-ISSN: 25807455.

25. Warasati, Bastian Sjafrial, "Memberantas KKN Lewat E-Procurement", Suara Karya, 1 Agustus 2005. www.hukumonline.com, "KKN, penyakit yang menyangkiti pengadaan barang and jasa pemerintah", Accessed on 17 Januari 2015.

26. Yetti,"'Implikasi Coorporate Social Responsibility (CSR) Terhadap Undang-Undang Nombor 5 Tahun 1999 tentang larangan Amalan Monopoli and Persaingan Usaha Tidak Sihat,"Respublika, November 2011, 45.

27. Electronic Source: http://kelilingriau.blogspot.co.id/2013/06/perusahaan-blacklistmenang-tender-di.html

28. Electronic Source: https://www.merdeka.com/peristiwa/proyek-kemen-pu- dikerjakanperusahaan-blacklist-di-pekanbaru.html

29. Electronic Source: http://www.alkonusa.com/news/definisi-kontraktor/ 